\section{Effects of Erythromycin and Its Derivatives on Interleukin-8 Release by Human Bronchial Epithelial Cell Line BEAS-2B Cells}

Sir:

Macrolide antibiotics are widely used as antimicrobial agents. Previously, we discovered that erythromycin (EM) and its derivatives with no antimicrobial activity have strong gastrointestinal motor-stimulating (GMS) activity ${ }^{1,2}$. We proposed the generic name 'motilide' for a series of macrolides with motilin-agonistic activity ${ }^{3,4)}$. About the same time, some macrolide antibiotics, especially EM-A and clarithromycin (CAM) have been reported to be effective against diffuse panbronchiolitis (DPB) which is one of chronic airway inflammatory diseases ${ }^{5,6)}$. Although therapeutic mechanisms of these macrolides are not yet clear, it is considered that those responses are due to anti-inflammatory action rather than antimicrobial action ${ }^{7}$. Furthermore, we previously reported that EM-A and CAM suppressed mRNA levels as well as the release of pro- inflammatory cytokines, interleukin (IL) -6 and IL-8 in human bronchial epithelial cell line BEAS-2B (BEAS$2 \mathrm{~B}$ cells) and primary normal bronchial epithelial cells ${ }^{8,9)}$. We report here the suppressive effect of IL-8 release, the antimicrobial activity and GMS activity of EM-A, CAM and EM derivatives (Fig. 1) and describe the structureactivity relationships.

BEAS-2B cells ${ }^{10}$ ) (a kind gift from Drs. J. F. LeChNeR and C. C. Harris, National Cancer Institute, Bethesda, MA) were cultured by the method reported previous$1 y^{8,9,11)}$ with some modification. The cells were plated onto collagen coated 24-well culture plates at a density of $1 \times 10^{5}$ cells/well in hormonally defined Ham's F12 medium (HD-F12). The HD-F12 contained 1\% penicillin-streptomycin, $5 \mu \mathrm{g} / \mathrm{ml}$ insulin, $5 \mu \mathrm{g} / \mathrm{ml}$ transferrin, $25 \mathrm{ng} / \mathrm{ml}$ epidermal growth factor, $15 \mu \mathrm{g} / \mathrm{ml}$ endothelial cell growth supplement, $2 \times 10^{-10} \mathrm{M}$ triiodothyronin and $10^{-7} \mathrm{M}$ hydrocortisone. The cells were incubated at $37^{\circ} \mathrm{C}$ in $95 \%$ air $-5 \% \mathrm{CO}_{2}$. Upon confluency, the cultured cells were washed with Hanks' balanced solution without calcium and magnesium, the media were replaced by fresh HD-F12, and $10^{-6} \mathrm{M}$ macrolide anti-

Fig: 1. Structures of erythromycin, its derivatives and clarithromycin.
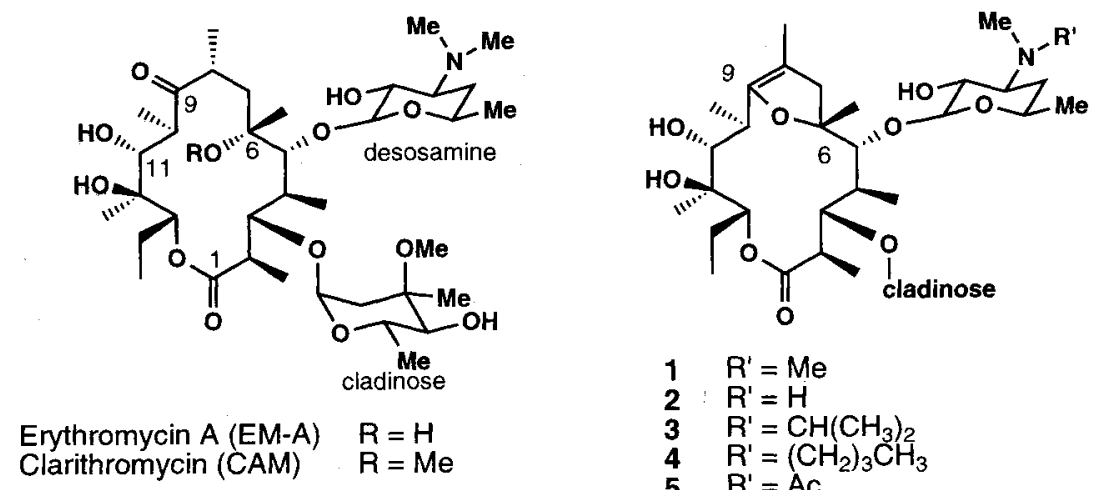

$$
\begin{array}{ll}
1 & R^{\prime}=\mathrm{Me} \\
2 & R^{\prime}=H \\
3 & R^{\prime}=\mathrm{CH}\left(\mathrm{CH}_{3}\right)_{2} \\
4 & R^{\prime}=\left(\mathrm{CH}_{2}\right)_{3} \mathrm{CH}_{3} \\
5 & \mathrm{R}^{\prime}=\mathrm{Ac} \\
6 & \mathrm{R}^{\prime}=\mathrm{Me},-\mathrm{CH}_{2} \mathrm{C} \equiv \mathrm{CH} \bullet \mathrm{Br}
\end{array}
$$

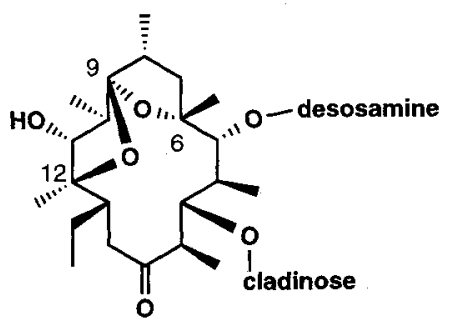

7

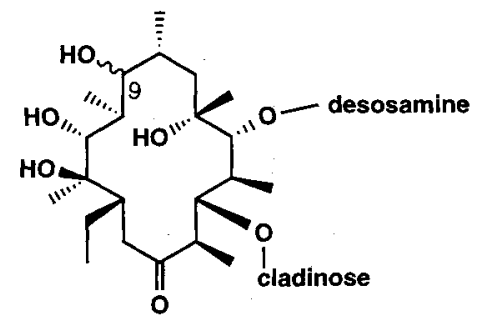

8 
Fig. 2. Effects of erythromycin (EM), its (EM) derivatives and clarithromycin (CAM) on IL-8 release by BEAS-2B cells.

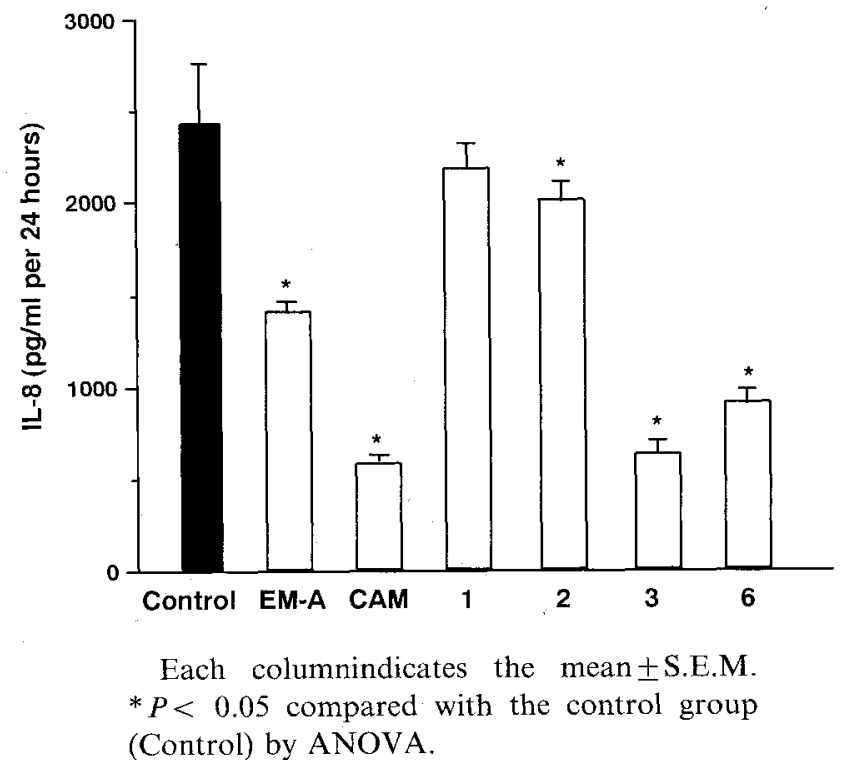

Fig. 3. Effects of erythromycin (EM) and its (EM) derivatives on IL- 8 release by BEAS-2B cells.

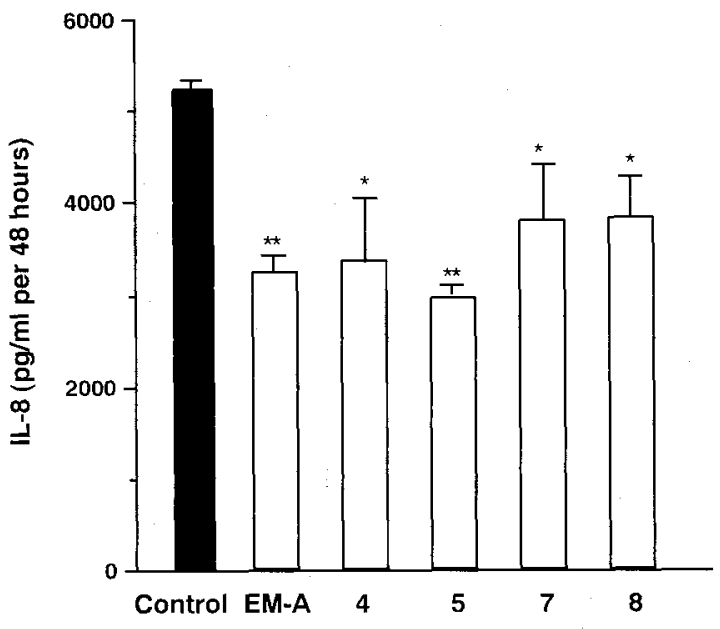

Each column indicates the mean \pm S.E.M. $* P<0.05, * * P<0.01$ compared with the control group (Control) by ANOVA.

Table 1. Antimicrobial activities (MIC) and gastrointestinal motor stimulating (GMS) activities of erythromycin, its derivatives and clarithromycin.

\begin{tabular}{|c|c|c|c|c|c|c|}
\hline \multirow{2}{*}{ Compound } & \multicolumn{5}{|c|}{ Antimicrobial activity $(\mathrm{MIC} ; \mu \mathrm{g} / \mathrm{ml})^{\mathrm{a}}$} & \multirow{2}{*}{ GMS acitivity $^{2}$} \\
\hline & $S A^{b}$ & BS & $\mathrm{BC}$ & EC & $\mathrm{KP}$ & \\
\hline Erythromycin A (EM-A) & 0.2 & 0.1 & 0.1 & 12.5 & 6.25 & $1^{\mathrm{C}}$ \\
\hline Clarithromycin (CAM) & 0.1 & 0.1 & 0.1 & 6.25 & 6.25 & 0.2 \\
\hline 1 & 50 & 25 & 25 & $>100$ & $>100$ & 10 \\
\hline 2 & $>100$ & $>100$ & $>100$ & $>100$ & $>100$ & 14.9 \\
\hline 3 & $>100$ & $>100$ & $>100$ & $>100$ & $>100$ & 248 \\
\hline 4 & $>100$ & $>100$ & $>100$ & $>100$ & $>100$ & 8.4 \\
\hline 5 & $>100$ & $>100$ & $>100$ & $>100$ & $>100$ & $<1$ \\
\hline 6 & 100 & 100 & 100 & $>100$ & $>100$ & 2890 \\
\hline 7 & 12.5 & ND & 6.25 & $>100$ & $>100$ & 3 \\
\hline 8 & 6.25 & 3.13 & 3.13 & $>100$ & $>100$ & 0.7 \\
\hline
\end{tabular}

a In the part of data, MIC and GMS activity of EM derivatives, were obtained from our previous reports ${ }^{1,12,13)}$.

b SA: Staphylococcus aureus ATCC 6538P. BS: Bacillus subtilis ATCC 6633. BC: Bacillus cereus IFO 3001. EC: Escherichia coli NIHJ. KP: Klebsiella pneumoniae ATCC 10031.

c The activity of EM-A was taken to be 1 .

biotics and their derivatives were added to each well, and incubated for 24 or 48 hours. Specific immunoreactivity for IL-8 in the cultured supernatants was measured by ELISA kits as described previously ${ }^{9)}$. The results were analyzed by non-parametric equivalents of analysis of variance (ANOVA) for multiple comparison as reported ${ }^{8,9,11)}$. Minimum inhibitory concentrations (MIC) of CAM and anhydro-erythromycin A (7) against test organisms were estimated by agar dilution method GMS activities of CAM and 7 were carried out by the method described previously ${ }^{1,2)}$. MIC and GMS activities of EM derivatives were obtained from our previous reports ${ }^{1,12,13)}$.

The results were shown in Figs. 2 and 3. EM-A exhibited similar suppressive effect on IL- 8 release by BEAS-2B cells which were treated with 24 or 48 hours. 
CAM, de( $N$-methyl)- $N$-isopropyl-8,9-anhydroerythromycin A 6,9-hemiacetal (3) and $N$-propargyl-8,9anhydroerythromycin A 6,9-hemiacetal bromide (6) exhibited the strong suppressive effect on IL- 8 release by the cells. EM-A, de( $N$-methyl)- $N$-butyl-anhydroerythromycin A 6,9-hemiacetal (4) and $\operatorname{de}(N$-methyl)- $N$ acetyl-anhydroerythromycin A 6,9-hemiacetal (5) exhibited moderate suppressive effect on IL- 8 release by the cells. 7 and 9-dihydro EM-A (8) exhibited weak effect on IL-8 release by the cells. 8,9-anhydroerythromycin A 6,9-hemiacetal (1) and de( $N$-methyl)-8,9-anhydroerythromycin A 6,9-hemiacetal (2) did not exhibit statistically significant effect on IL-8 release by the cells. Furthermore, we studied the effects of methymycin (12-membered macrolide), and oleandomycin, spiramycin, tylosin and rokitamycin (16-membered macrolides) in this system. But those macrolides did not exhibit statistically significant effect when added to the cells at $10^{-6} \mathrm{M}$ (data no shown). Our findings suggest that 14-membered macrolide such as EM had specifically suppressive effect on the release of cytokine such as IL-8 from bronchial epithelial cells.

The antimicrobial and GMS activities of EM derivatives were shown in Table 1 in comparison with these activities and the suppressive effect of EM derivatives on IL-8 release. There are no relationship among the suppressive effect of IL-8 release, MIC and GMS activities. Among derivatives, compound $\mathbf{5}$ is the most interesting, because this compound showed the moderate suppressive effect of IL-8 release, but no antimicrobial and GMS activities,

We are further investigating for a possible development of a new type anti-inflammatory agent in EM derivatives.

\section{Acknowledgment}

We wish to thank Drs. I. TAKAHASH and Z. ITOH, Gunma University, for the GMS assay, and Dr. R. MASUMA, the Kitasato Institute, for the MIC assay.

Toshiaki Sunazuka HAJIME TAKIZAWA ${ }^{\dagger}$ MASASHI DESAKI ${ }^{\dagger}$ Kunihiko SuZuki

RiKa OBata KAZUHIKO OTOGURO SATOSHI ÖMURA*

Research Center for Biological Function, The Kitasato Institute, 5-9-1 Shirokane, Minato-ku, Tokyo 108-8642, Japan
${ }^{\dagger}$ Department of Medicine and Physical Therapy, University of Tokyo, School of Medicine, 7-3-1 Hongo, Bunkyo-ku, Tokyo 113-0033, Japan

(Received September 21, 1998)

\section{References}

1) Ōmura, S.; K. Tsuzuki, T. Sunazuka, H. Toyoda, I. TAKAHASHI \& Z. ITOH: Gastrointestinal motor-stimulating activity of macrolide antibiotics and the structure-activity relationship. J. Antibiotics 38: $1631 \sim 1632,1985$

2) Ōmura, S.; K. Tsuzuki, T. Sunazuka, S. Marui, H. TOYODA, N. INATOMI \& Z. IтоH: Macrolides with Gastrointestinal motor stimulating activity. J. Med. Chem. 30: $1941 \sim 1943,1987$

3) Kondo, Y.; K. ToriI, S. ŌMURA \& Z. ITOH; Erythromycin and its derivatives with motilin-like biological activities inhibit the specific binding of $125 \mathrm{I}$-motilin to duodenal muscle. Biochem. Biophys. Res. Commun.150: $877 \sim 882$, 1988

4) ŌMura, S.; Y. Kondo.\& Z. ITOH: Motilide, motilin-like macrolide. In Motilin. Ed., Z. Iтон, pp. 245 256, Academic Press, New York, 1990

5) Kudoh, S.; T. Uetake, K. Hagiwara, M. Hirayama, L.-H. Hus, H. Kimura \& Y. SugiYama: Clinical effect of low-dose, long-term erythromycin chemotherapy on diffuse panbronchiolitis. Jpn. J. Thorac. Dis. 25: $632 \sim 642,1987$

6) Takeda, H.; H. Miura, M. Kawahira, H. Kobayashi, S. OTOMO \& S. NAKAIKE: Long-term administration study on TE-031 (A-56268) in the treatment of diffuse panbronchiolitis. Kansenshogaku Zasshi 63: 71 78, 1989

7) Miyatake, H; F. Taki, H. Taniguchi, R. Suzuki, K. TAKagi \& T. SATAKe: Erythromycin reduces the severity of bronchial hyperresponsiveness in asthma. Chest 99: $670 \sim 673,1991$

8) Takizawa, H.; M. Desaki, T. Ohtoshi, T. Kikutani, H. Okazaki, M. Sato, N. Akiyama, S. Shoji, K. Hiramatsu \& K. ITO; Erythromycin suppresses interleukin 6 expression by human bronchial epithelial cells. Biochem. Biophys. Res. Commun. 210: $781 \sim 786,1995$

9) TAKizawa, H.; T. OHTosh \& K. ITO: Human bronchial epithelial cells produce cytokines relevant airway inflammation. ACI News 6: 146 150, 1994

10) Reddel, R. R.; Y. Ke, B. I. Gerwin, M. McMenamin, J. F. Lechner, R. T. Su, D. E. Brash, J. B. Park, J. S. RHIM \& C. C. HARRIs: Transformation of human bronchial epithelial cells by infection with SV40 or adenovirus-12/SV 40 hybrid virus, or transfection via strontium phosphate coprecipitation with a plasmid containing SV40 early region genes. Cancer Res. 48: 1904 1909, 1988

11) Takizawa, H,; T. Ohtoshi, K. Ohta, S. Hirohata, M. Yamaguchi, N. Suzuki, T. Ueda, A. Ishil, G. Shindoh, T. OKa, K. Hiramatsu \& K. Ito: Interleukin $6 / \mathrm{B}$ cell stimulatory factor -2 is expressed and released by normal and transformed human bronchial epithelial cells. Biochem. Biophys. Res. Commun. 187: 569 602, 1992

12) Tsuzuki, K.; T. Sunazuka, S. Marui, H. Toyoda, S. Ömura, N, InAtomi \& Z. IтоH: Motilides, macrolides with gastrointestinal motor stimulating activity. I. 
$O$-Substituted and tertiary $N$-substituted derivatives of 8,9-anhydroerythromycin A 6,9-hemiacetal. Chem. Pharm. Bull. 37: 2687 2700, 1989

13) Sunazuka, T.; K. Tsuzuki, S. Marui, H. Toyoda, S ŌMURA, N, INATOMI \& Z. ITOH: Motilides, macrolides with gastrointestinal motor stimulating activity. II. Quaternary $N$-substituted derivatives of 8,9-anhydroerythromycin A 6,9-hemiacetal and 9,9-dihydroerythromycin A 6,9-epoxide. Chem. Pharm. Bull. 37: 2701 2709,1989 